\title{
ETHIDIUM BROMIDE-INDUCED DEMYELINATION IN THE SCIATIC NERVE OF DIABETIC RATS
}

\author{
Eduardo Fernandes Bondan ${ }^{1,2}$, Paulo Ruggiero Custódio², Maria Anete Lallo ${ }^{1,2}$, \\ Henri Donnarumma Levy Bentubo ${ }^{2}$, Dominguita Luhers Graça ${ }^{3}$
}

\begin{abstract}
This study aims to observe the process of myelin loss and repair following the injection of the gliotoxic agent ethidium bromide (EB) in the sciatic nerve of rats previously induced to diabetes mellitus by streptozotocin. Injection of EB was also done in non-diabetic rats. The animals were euthanatized from 3 to 31 days after intraneural injection and nerve sections were collected for ultrastructural study. In nondiabetic rats, Schwann cells (CS) showed signs of intoxication 3 days after, with cytoplasmic vacuolization and rejection of their myelin sheaths. Myelin debris were removed by macrophages in the endoneurium and mast cells were abundant in the lesions. From 14 days following EB injection, supernumerary CS were seen in the expanded endoneurium as well as thin myelin sheaths indicating remyelination. Diabetic rats presented a more extensive myelin vesiculation and segmentar demyelination, with delayed activities from both macrophages and remyelinating SC. No mast cells were noted.
\end{abstract}

KEY WORDS: demyelination, diabetes mellitus, ethidium bromide, peripheral nervous system, remyelination, Schwann cells.

\section{Desmielinização induzida pelo brometo de etídio no nervo ciático de ratos diabéticos}

Resumo - O estudo visa à observação do processo de perda e reparo mielínico pós-injeção do gliotóxico brometo de etídio (BE) no nervo ciático de ratos previamente induzidos a diabetes mellitus pela estreptozotocina. Injeção de BE foi igualmente realizada em ratos não-diabéticos. Os animais foram eutanasiados dos 3 aos 31 dias pós-injeção intraneural, com colheita de amostras neurais para estudo ultraestrutural. Nos animais não-diabéticos, as células de Schwann (CS) mostraram sinais de intoxicação a partir dos 3 dias pós-gliotóxico, com vacuolização citoplasmática e rejeição de suas bainhas de mielina. Restos mielínicos eram removidos por macrófagos no interior do endoneuro e mastócitos eram abundantes nas lesões. A partir dos 14 dias, CS supranumerárias foram encontradas no endoneuro expandido, além de finas bainhas de mielina indicativas de remielinização. Os ratos diabéticos apresentaram vesiculação mielínica e desmielinização segmentar mais extensas, bem como ausência de mastócitos e atraso na atividade macrofágica e na função remielinizante das CS.

PALAVRAS-CHAVE: brometo de estídio, células de Schwann, desmielinização, diabetes mellitus, remielinização, sistema nervoso periférico.

The gliotoxic agent ethidium bromide (EB) induces early astrocyte disappearance and oligodendroglial loss when injected in the central nervous system (CNS) leading to blood-brain barrier disruption and primary demyelination respectively. Subsequent remyelination occurs performed by surviving oligodendrocytes and by invasive Schwann cells ${ }^{1-6}$. After local EB injection in the peripheral nervous system (PNS) no destruction of myelinating cells but rather intoxication of Schwann cells is observed ${ }^{7}$. Although Schwann cells are highly resistant to a broad span of spontaneous and experimental injuries ${ }^{8}$ these intoxicated cells soon reject their myelin sheaths as their ability to maintain the internodes is compromised, thus causing a similar demyelinating process.

Diabetes mellitus is also known to disturb the functioning and integrity of Schwann cells as they are a pri-

'Programa de Mestrado em Imunopatologia, Universidade Paulista, São Paulo SP, Brasil (UNIP); ${ }^{2}$ Universidade Cruzeiro do Sul, São Paulo SP, Brasil (UNICSUL); ${ }^{3}$ Departamento de Patologia, Universidade Federal de Santa Maria, Santa Maria RS, Brasil (UFSM).

Received 10 April 2009. Accepted 3 August 2009.

Dr. Eduardo Fernandes Bondan - Rua Caconde 125 / 51 - 01425-011 São Paulo SP - Brasil. E-mail: bondan@uol.com.br 
mary target of polyol pathway abnormalities linked to related hyperglycemia ${ }^{6}$.

The aim of this study was to observe the behaviour of Schwann cells facing a double challenge (the gliotoxic drug injection in the sciatic nerve and hyperglycemia caused by the streptozotocin diabetogenic model) in order to see if they still maintain their survival capacity or their ability of reconstructing myelin sheaths.

\section{METHOD}

Twenty-nine adult male Wistar rats were divided into 5 groups. Induction of diabetes mellitus was performed using a single intraperitonial injection of $50 \mathrm{mg} / \mathrm{kg}$ streptozotocin in $10 \mathrm{mM}$ sodium citrate buffer $(\mathrm{pH} 4.5)$ after $12 \mathrm{~h}$ of fasting. Ten days later blood glucose levels were measured and animals with levels of $200 \mathrm{mg} / \mathrm{dL}$ or more were considered to be diabetic. At that time some were submitted to a intraneural injection of 1 microliter of $0.1 \%$ EB (group I, $\mathrm{n}=10$ ) or $0.9 \%$ saline solution (group II, $\mathrm{n}=5$ ), while others did not receive any nerve injection and were used as a diabetic / histologic control group (group III, $n=2$ ). Other groups included non-diabetic animals: group IV, rats injected with 1 microliter of $0.1 \%$ EB solution $(n=10)$ and $V$ non-diabetic / histologic control group ( $n=2)$. The EB or saline injected rats were anesthetized with ketamine and xylazine $(5: 1 ; 0.1 \mathrm{~mL} / 100 \mathrm{~g}$ ) and a single injection of $1 \mathrm{mi}-$ croliter of $0.1 \%$ EB or $0.9 \%$ saline solution was performed freehand on the middle third of the left sciatic nerve using a Hamilton syringe fitted with a $35^{\circ}$ angled polished 26-gauge needle. The localization of the lesions was facilitated by a stitch in the adjacent semitendinous muscle. Stance, gait and social behavior were recorded daily. Body weight and blood glucose levels (Dextrostix, Ames Laboratory, IA, USA) were recorded on 3 occasions - at the time of streptozotocin injection, 10 days later and at the time of sacrifice. Rats were kept under controled light conditions (12h light-dark cycle) and water and food were given ad libitum during the experimental period.

Three animals from groups I and IV and 1 from group II were euthanatized at each of the following periods -3 , 7, 14, 21 and 31 days - and nerve samples from both hind limbs were collected (Figs 1, 2 and 3). The samples were cut into 5 transverse fragments, washed in PBS, fixed in $4 \%$ glutaraldehyde in $0.1 \mathrm{M}$ sodium phosphate buffer ( $\mathrm{pH} 7.4)$ for 48 hours, post-fixed in $0.1 \%$ osmium tetroxide, dehydrated in graded acetones solutions and embedded in Araldite 502 resin, following transitional stages in acetone. Thick sections were stained with $0.25 \%$ alkaline toluidine blue. Selected areas were trimmed and thin sections were stained with $2 \%$ uranyl and lead citrate and viewed in a JEM 1200 EX2 JEOL transmission electron microscope.

\section{RESULTS}

No change was seen in stance or gait in any rat used

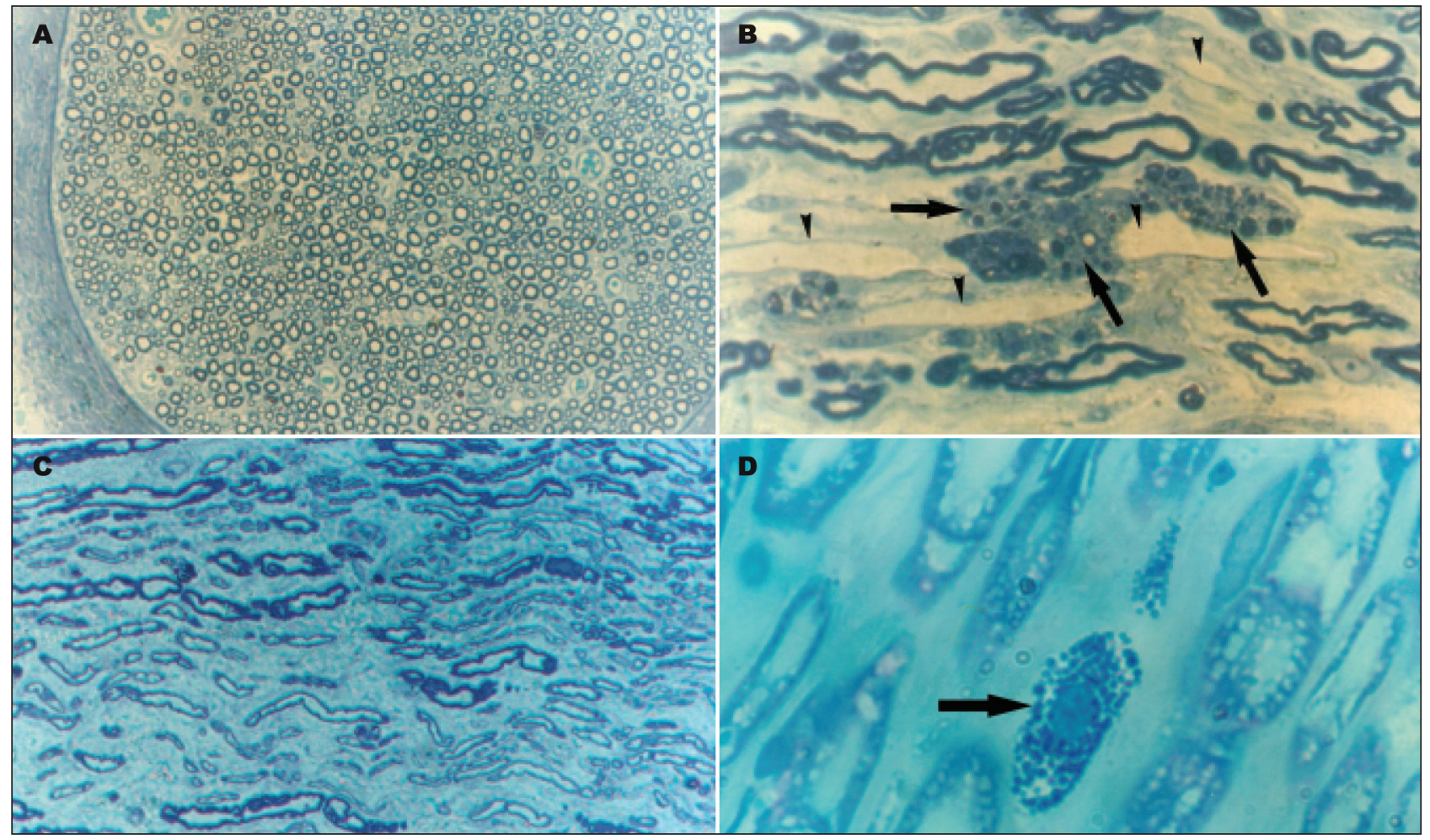

Fig 1. [A] Normal aspect of the sciatic nerve. Group V (non-diabetic / histologic control group); [B] Demyelinated axons (arrowheads) and macrophages (arrows) containing phagocytosed myelin at 7 days after EB injection. Group IV (non-diabetic); [C] Axons with normal and thinly remyelinated sheaths 14 days post-injection. Group IV; [D] Mast cell at 14 days after EB injection. Toluidine blue. 


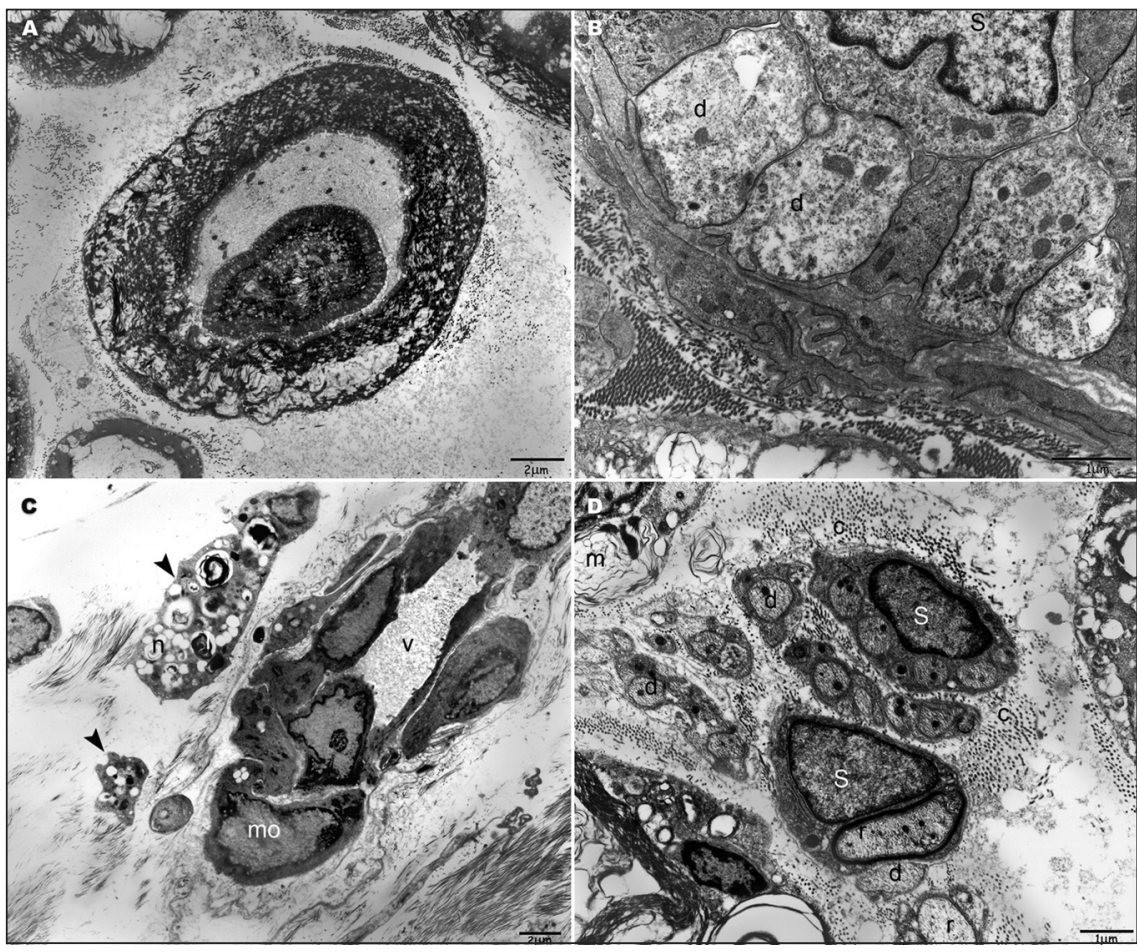

Fig 2. [A] Myelin vesiculation 3 days after the gliotoxic injection. Note the absence of Schwann cell cytoplasm. Bar $=2 \mu \mathrm{m} ;[B] \mathrm{De}-$ myelinated axons (d) 7 days after EB injection. Observe the presence of an associated Schwann cell (S). Bar=1 $\mu \mathrm{m}$; [C] Monocyte migration ( $\mathrm{mo}$ ) from a blood vessel ( $v$ ) 14 days after EB injection. Note the presence of macrophages (arrowheads) containing myelin in different stages of degradation, from the visualization of lamellae (l) to neutral fat droplets (n). Bar $=2 \mu \mathrm{m} ;[D]$ General aspect of the center of the lesion 21 days after $E B$ injection. Presence of Schwann cells (S) associated to demyelinated axons (d) and even in remyelination ( $r$ ) Note the great amount of collagen fibers (c) in the extracellular space as well as vesiculated myelin (m). Bar=1 $\mu \mathrm{m}$. Electron micrographs. Group I (diabetic).
Fig 3. [A] Schwann cell (S) close to demyelinated axons (d) 21 days after EB injection. Presence of detached myelin $(\mathrm{m})$ and collagen fibers (c) in the extracellular space. Bar $=1 \mu \mathrm{m}$. $[B]$ General aspect of the EB-induced lesion 21 days post-injection. Note the presence of axons in remyelination $(r)$, vesiculated myelin $(m)$ in the extracellular space, a macrophage (M) in phagocytic activity and collagen fibers (c). Bar $=2 \mu \mathrm{m} ;[\mathrm{C}]$ Axon in remyelination at 21 days. Observe the presence of basal lamina (arrow) over the Schwann cell cytoplasm (asterisk) and collagen fibers (c) in the extracellular space. Bar $=1 \mu \mathrm{m} ;[D]$ Axon (A) with myelin in process of detachment 21 days after EB. Collagen fibers (c). Bar $=2 \mu \mathrm{m}$. Electron micrographs. Group I (diabetic).

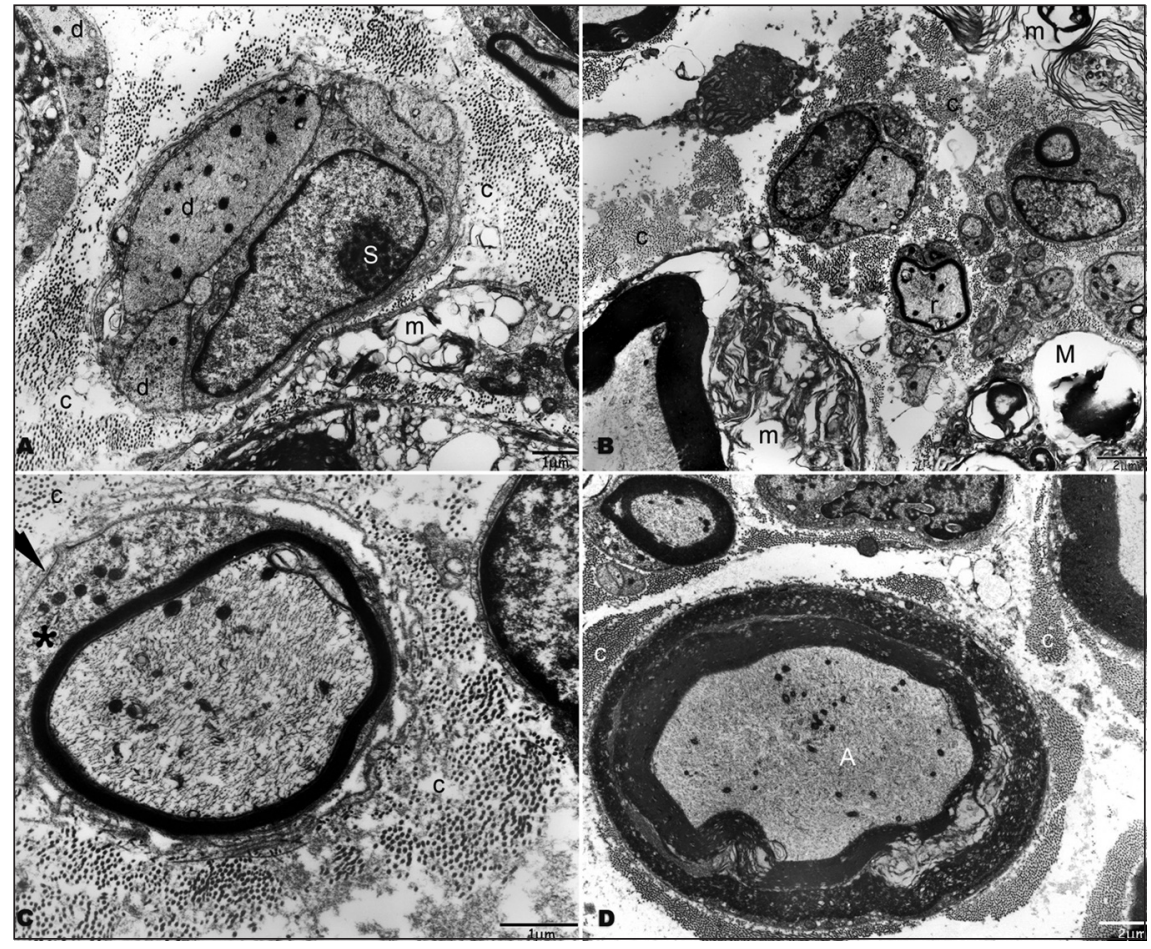

in this investigation. The EB-induced lesions in the sciatic nerve of non-diabetic rats (group IV) were similar to those described by Riet-Correa and colleagues ${ }^{7}$. Altough there was some variation in the extent of the demyelinated area, most of the lesions were $5 \mathrm{~mm}$ in length and presented segmental demyelination and clearance of cellu- lar debris by macrophages followed by extensive myelin repair by Schwann cells.

Three days after intraneural EB injection signs of Schwann cell intoxication were noticed with cytoplasmic vacuolization, myelin changes such as progressive condensation of the outer lamellae and vesiculation which lead 
to a complete rejection of its own myelin sheath. Macrophagic infiltration within the endoneurium was proeminent and these cells presented phagocytosed myelin in several stages of degradation, including lamellae and neutral fat droplets, in areas of enlarged extracellular space containing occasional lattices of myelin-derived membranes. Mast cells were commonly observed in the endoneurium as well as few lymphocytes and neutrophils. There was no sign of axonal damage outside the needle track. At 7 days it was possible to observe the approximation of Schwann cells to some demyelinated axons. From 14 days after gliotoxic injection a great number of Schwann cells were seen progressively associated to one or more demyelinated axons or already producing thin myelin sheaths around individual internodes in an expanded extracellular space, where collagen fibers were depicted. Some of these remyelinating Schwann cells presented intracytoplasmic myelin granules and were covered by a dense basal lamina which was surrounded by a great amount of collagen fibers. At 21-31 days it was clearly apparent a reorganization of the nerve fascicles with axons covered by thin and thicker sheaths separated by an increased deposition of collagen. Few axons remained completely naked and some stayed clustered.

All rats submitted to the streptozotocin injection presented hyperglycemia (levels from 200 to $600 \mathrm{mg} / \mathrm{dL}$ ) on the $10^{\text {th }}$ day and on day of euthanasia. During the experimental period the diabetic rats developed characteristic polyuria, polydipsia and body weight loss.

No evidence of either primary demyelination or loss of the neuroglia was found in rats from groups II (diabetic rats which received intraneural injection of saline solution), III (control group of diabetic rats) and V (control group of non-diabetic rats).

In the diabetic rats from group I it was observed, from 3 days after the injection of EB, a larger amount of apparently intoxicated Schwann cells, leaving their sheaths with higher frequency than that noticed in non-diabetic rats from group IV, and thus intensifying myelin vesiculation and detachment. By 7 days a greater number of demyelinated axons was found in the central site of the lesions. Although macrophages were present, the observation of huge amounts of myelin-derived membranes in the extracellular space apparently suggested that their scavenging activity was somehow affected by the diabetic state. Mast cells were not found in the endoneurium of diabetic animals and the presence of lymphocytes and neutrophils was less frequent. From the $14^{\text {th }}$ to the $31^{\text {st }}$ day post-injection few axons exhibited light myelin sheaths with the great majority of axons remaining naked although associated to Schwann cells, so indicating an apparent possibility of future remyelination. Comparing to group IV (nondiabetic), the diabetic one (group I) presented clearly at
21-31 days a marked delay in the remyelinating acitivity of Schwann cells on previously demyelinated internodes.

\section{DISCUSSION}

The EB injection in the sciatic nerve induced segmentar demyelinating lesions, with subsequent remyelination by Schwann cells, in an identical way of that already described by Riet-Correa and colleagues ${ }^{7}$. Several studies reported the invasive capacity of Schwann cells into the CNS from spinal or cranial nerves due to the glia limitans disruption following injection of the gliotoxin ${ }^{1-5}$. This invasion however appeared to be diminished in the diabetic state induced by streptozotocin treatment ${ }^{6}$.

The lack of clinical signs in the rats from this investigation was atributted to the fact that the sciatic nerve is a multifascicular nerve so that the drug or the needle used in the injection have never affected all fascicles.

Contrasting to the CNS where glial cells (astrocytes and oligodendrocytes) were invariably destroyed by the gliotoxic agent, Schwann cells were still present in our study although showing signs of disturbance and so abandonning the axons which they were related to and extruding their myelin sheaths from the cytoplasm. As emphasized by Cavanagh ${ }^{8}$ Schwann cells show a notable capacity of resistance to a broad range of injurious stimuli.

The EB-intoxicated Schwann cells excluded the internodes they surrounded and debris of these structures were phagocytosed appearing as cytoplasmic granules of myelin ${ }^{7}$, although the major phagocytic activity was undoubtedly performed by macrophagic infiltration. In spite of the fact that Schwann cells are able to produce collagen fibers themselves, activated macrophages can secrete molecules such as interleukin-1 (IL-1) and nerve growth factor (NGF) which stimulate fibroblasts to produce and secrete even more collagen ${ }^{7}$.

Even though Cavanagh ${ }^{8}$ described the common proliferation of mast cells in PNS diseases the real meaning of their presence in the EB-demyelinating lesions remains unexplained.

Schwann cell disturbance followed by segmental demyelination in the PNS is a prominent finding in diabetes mellitus of humans ${ }^{9}$ and cats $^{10}$, but this is not so commonly observed in spontaneous or experimental diabetes in rats ${ }^{6}$.

Although similar cellular phenomena related to the EB model in the PNS have appeared in streptozotocin-diabetic rats, it was noted that the temporal pattern of repair was somehow different from that seen in non-diabetic rats. The finding of huge amounts of myelin-derived membranes in the PNS demyelinating lesions of diabetic rats resembled the one observed in the brainstem of rats immunosuppressed with cyclophosphamide ${ }^{3}$ or dexamethasone ${ }^{4}$ as well as in streptozotocin-diabetic rats ${ }^{5}$ in which was observed a delay in the scavenging activi- 
ty of macrophages and in the subsequent CNS remyelinating process. Short-term diabetes mimics lesions of slow development induced by EB in the rat CNS and delays all the subsequent repair events ${ }^{5}$. Furthermore abnormal macrophage function has been described in diabetes mellitus ${ }^{9,11}$ and may explain why clearance of cellular debris tends to be a longer-term process in the diabetic group.

Insulin and insulin-growth factor (IGF-1) are known to be important stimulating factors for Schwann cells ${ }^{12-14}$, but their levels are decreased in experimental streptozotocin diabetes ${ }^{15-16}$. Besides as Schwann cells do not need insulin for glucose transport across membrane hyperglycemia frequently causes intracellular glucose accumulation and increased polyol pathway activity by aldose reductase resulting in increased levels of sorbitol and fructose, which may cause osmotic swelling and cell death?

Increased vulnerability induced by diabetes to myelin loss in the PNS is described by some authors ${ }^{17-18}$ and this was atributted to the fact that Schwann cells are susceptible to metabolic disarrangements due to hyperglycemia. As diabetes itself can interfere on Schwann cell integrity and function the use of a glitoxic agent represent an additional disturbing influence, maybe explaining the greater demyelination and the lesser remyelination found in the diabetic group when compared to the non-diabetic one.

It is important to mention that the EB-demyelinating model in the PNS leads to the observation that Schwann cells maintain the potential of reconstructing myelin internodes after their transient intoxication in non-diabetic animals. By contrast there was an apparent delay in the whole remyelinating process as well as in the phagocytic activity in the lesions of diabetic rats, similar to that found in the brainstem of diabetic animals ${ }^{5}$, indicating that their outstanding potential to remyelinate after EB gliotoxic damage is somehow compromised by the diabetic state.

\section{REFERENCES}

1. Blakemore WF. Ethidium bromide induced demyelination in the spinal cord of the cat. Neuropathol Appl Neurobiol 1982;8:365-375.
2. Graça DL, Blakemore, WF. Delayed remyelination in the rat spinal cord following ethidium bromide injection. Neuropathol Appl Neurobiol 1986;12:593-605.

3. Bondan EF, Lallo MA, Sinhorini IL, Pereira, LAVD, Graça DL. The effect of cyclophosphamide on the rat brainstem remyelination following local ethidium bromide injection in Wistar rats. J Submicrosc Cytol Pathol 2000;32:603-612.

4. Bondan EF, Lallo MA, Baz, EI, Sinhorini IL, Graça DL. Estudo ultra-estrutural do processo remielinizante pós-injeção de brometo de etídio no tronco encefálico de ratos imunossuprimidos com dexametasona. Arq Neuropsiquiatr 2003;62:131-138.

5. Bondan EF, Lallo MA, Trigueiro AH, Ribeiro CP, Sinhorini IL, Graça DL. Delayed Schwann cell and oligodendrocyte remyelination after ethidium bromide injection in the brainstem of Wistar rats submitted to streptozotocin diabetogenic treatment. Braz J Med Biol Res 2006;39:637-646.

6. Bondan EF, Lallo MA, Graça, DL. Ultrastructural study of the effects of cyclosporine in the brainstem of Wistar rats submitted to the ethidium bromide demyelination model. Arq Neuropsiquiatr 2008;66:378-384.

7. Riet-Correa G, Fernandes CG, Pereira LAV, Graça DL. Ethidium bromide-induced demyelination of the sciatic nerve of adult Wistar rats. Braz J Med Biol Res 2002;35:99-104.

8. Cavanagh JB.Reaction of neurons and Schwann cells to injury. In: Weller RO (Ed). Nervous system, muscle and eyes. 3.Ed. London: Churchill Livingstone, 1990:533-543.

9. Cotran RS, Kumar V, Collins SL. Robbins: pathologic basis of disease. Philadelphia: W.B. Saunders, 2000

10. Mizisin AP, Shelton GD, Wagner S, Rusbridge SWC, Powell HC. Myelin splitting, Schwann cell injury and demyelination in feline diabetic neuropathy. Acta Neuropathol 1998;95:171-174.

11. Geisler C, Almdal T, Bennedsen J, Rhodes JM, Kolendorf K Monocyte functions in diabetes mellitus. Acta Pathol Microbiol Immunol Scand 1982;90:33-37.

12. Dubovy P, Svizenska I. Migration of Schwann cells from the distal stump of the sciatic nerve 1 week after transection: the effects of insulin and cytosine arabinoside. Glia 1992;6:281-288.

13. Jung-Testas I, Schumacher M, Robel P, Baulieu EE. Actions of steroid hormones- and growth factors on glial cells of the central and peripheral nervous system. J Steroid Biochem Molec Biol 1994;48:145-154.

14. Schumacher M, Jung-Testas I, Robel P, Baulieu EE. Insulin-like growth factor I: a mitogen for rat Schwann cells in the presence of elevated levels of cyclic AMP. Glia 1993;8:232-240.

15. Crosby SR, Tsigos C, Anderton CD, Gordon C, Young RJ, White A. Elevated plasma insulin-like growth factor binding protein-1 levels in type 1 (insulin-dependent)diabetic patients with peripheral neurophaty. Diabetologia 1992;35:868-872.

16. Goldstein S, Sertich GJ, Levan KR, Philips LS. Nutrition and somatomedin. XIX. Molecular regulation of insulin-like growth factor-1 in streptozotocin-diabetic rats. Melec Endocrinol 1988;2:1093-1100.

17. Dockery, P Sharma AK. Ultrastructural abnormalities of myelinated fibers in the tibial nerve of streptozotocin diabetic rats. J Neurol Sci 1990;98:327-345,1990.

18. Jaffey PB, Gelman BB. Increased vulnerability to demyelination in streptozotocin diabetic rats. J Comp Neurol 1996;373:55-61. 